This is the author's final, peer-reviewed manuscript as accepted for publication. The publisher-formatted version may be available through the publisher's web site or your institution's library.

\title{
Work as a source of positive emotional experiences and the discourses informing positive assessment
}

Pamela Lutgen-Sandvik, Sarah Riforgiate, \& Courtney Fletcher

\section{How to cite this manuscript}

If you make reference to this version of the manuscript, use the following information:

Lutgen-Sandvik, P., Riforgiate, S., \& Fletcher, C. (2011). Work as a source of positive emotional experiences and the discourses informing positive assessment. Retrieved from http://krex.ksu.edu

\section{Published Version Information}

Citation: Lutgen-Sandvik, P., Riforgiate, S., \& Fletcher, C. (2011). Work as a source of positive emotional experiences and the discourses informing positive assessment. Western Journal of Communication, 75(1), 2-27.

Copyright: ( 2011 Western States Communication Association

Digital Object Identifier (DOI): doi:10.1080/10570314.2010.536963

Publisher's Link: http://dx.doi.org/10.1080/10570314.2010.536963

This item was retrieved from the K-State Research Exchange (K-REx), the institutional repository of Kansas State University. K-REx is available at http://krex.ksu.edu 
Running head: POSITIVE EMOTIONAL EXPERIENCES AT WORK

\author{
Work as a Source of Positive Emotional Experiences \\ and the Discourses Informing Positive Assessment
}

\begin{abstract}
This study updates and extends current understandings of the organizational experiences likely to evoke positive emotions by examining 835 U.S. employees’ responses of their best workplace experiences. Responses included 17 positive experiences (recognition, relationships, reward, autonomy, appreciation, success, boss/mentorship, climate, opportunity, teamwork, resources, altruistic work, voice, social support, flexibility, challenge, triumph, and commitment) that typified five social discourses (power-empowerment, individualism-uniqueness, successaccomplishment, belonging-affiliation, and safety-security). Employee responses underscore the idea that the experiences at work evoking positive emotions are predominantly social (positive affective responses to others) and rooted in social, historical discourses or systems of meaning.
\end{abstract}

Keywords: positive organizing, positive organizational scholarship, positive emotions, job satisfaction, organizational communication

Author note: We presented an earlier version of this article at the National Communication Association’s 2009 annual convention where it earned a Top Paper Award in the Organizational Communication Division. We would like to thank the University of New Mexico for funding that supported this project and the journal editor and reviewers for feedback improving the article.

Notwithstanding the tendency to focus on the pitfalls and problems of organizational life, being an organization member can also provide extraordinary, positive experiences. Sensing others’ appreciation can make endeavors feel worthwhile and open creative channels in previously 
unrecognized directions. A heart-felt thank-you can contribute to an overall sense of contentment, infusing a positive mood workers subsequently bring home. Receiving an important award or promotion can affirm positive identities and uncover sources of strength and confidence. Positive emotion is the "pleasant feelings induced by commonplace events or circumstances” (Isen \& Baron, 1991, p. 1) is associated with improved overall health and longevity; increased altruism, courtesy, and conscientiousness in organizations; enhanced tendencies to assist others; and increased creativity and innovation (Cameron, 2008). Although organizational research typically explores negative dynamics and processes, examining the other side of the coin, so to speak, is of equal importance given these benefits. Because organizational life does afford feel-good experiences, an understanding the full range of such experiences could help individuals, groups, and organizations capitalize on the associated benefits.

Identifying the full range of positive workplace experiences is useful because current scholarship about positive organizing is variable-specific, that is research typically examines one variable at a time (e.g., hope, virtuousness, optimism, etc.). Although important in its own right, identifying the full range of positive experiences could open possibilities for exploration that researchers may not have considered, such as how positive experiences overlap and co-occur. What is more, positive organizational research typically gives scant attention to the discourses or cultural, historical systems of meanings that inform positive assessment (for exceptions see Harré, 1986; Parkinson, 1996). Understanding these meaning systems is equally important, as they inform a host of organizational experiences both positive and negative.

To gain a fuller picture of the experiences that evoke positive emotion for contemporary U.S. workers, we examined responses to the prompt: "Please describe your best workplace experience.” From these responses we developed a best-job-experience typology and from the typology theorized about the systems of meaning likely to inform positive assessment. In what follows, we provide an 
overview of positive organizational themes and outline Harré's (1986) and Parkinson’s (1996) theories of emotions as social, from which we build our central arguments. We then examine the benefits and limitations of positive emotion for organizations and their members and follow this by detailing the current study's methods and analysis. We move on to describe the types of best-work experiences, experiences we axially coded using the theoretical discourses we believed the experiences typified. Finally, we examine the implications of the study, note the study’s limitations, and suggest areas for future work.

\section{Positive Organizational Phenomena}

\section{The Study of Positive Organizational Phenomena}

By and large, organizational researchers are moved to understand and solve specific problems. Complementary perspectives are positively oriented approaches alternately called positive organizational behavior (POB), positive organizational communication scholarship (POCS), positive organizational scholarship (POS), and, more generally, positive organizing. POS explores "positive outcomes, processes, and attributes of organizations and their members” focusing on organizationallevel phenomena (Cameron, Dutton, \& Quinn, 2003, p. 4), while POB concentrates on individuallevel behavior and improved performance (Luthans, 2002). POCS has yet to emerge as a fully developed field of study but generally centers on how communication and social discourse constitute organizations and organizing in constructive ways. Positive organizing is a general term that "refers to the generative dynamics in and of organizations that enable individuals, groups, and organizations as a whole to flourish” and bridges POS and POB (Fredrickson \& Dutton, 2008, p. 1). We adopt the term positive organizing (as opposed to POCS “pox”), as it encompasses micro-to-macro processes and, we believe, has the most potential to embrace communication-as-constitutive, a key perspective in the communication field (e.g., Craig, 1999).

For the most part, positive organizing research examines specific constructs. In the communication field, scholars have examined processes associated with constructive organizing 
(Lutgen-Sandvik \& Sypher, 2009), hope and community building (Barge, 2003), resilience as a response to adversity (Buzzanell, Shenoy, Remke, \& Lucas, 2009), and the communicative constitution of positive identities (LeBaron, Glenn, \& Thompson, 2009). In other organizational literature, researchers have explored particularized constructs such as virtuousness (Cameron, Bright, \& Caza, 2004), upward spirals (Fredrickson, 2003), compassion (Frost, Dutton, Worline, \& Wilson, 2000), positive relationships (Dutton \& Ragins, 2006), and positive identities (Roberts \& Dutton, 2009). Aside from Herzberg and colleagues' (1959) work (an outstanding study but somewhat dated and based solely on males), scholarship lacks a contemporary picture of the full range of experiences that evoke positive emotion at work. In addition, understanding the social forces informing emotional assessment of job experiences is important, especially for researchers wanting to play a role in creating more humane workplaces (Waldron, 2000). Which experience evokes what emotion necessarily differs among people and depends on the assessment of meaning given to these experiences, a point to which we now turn.

\section{Assessing Positive Meaning}

Core arguments from Harré’s (1986) and Parkinson’s (1996) social constructionist theories of emotions explain the factors and forces associated with positive assessment of experience. Harré claims that "all emotions are intentional — that is, they are 'about' something, in a very general sense" (p. 8). People respond emotionally to perceptions about someone or something external to them-an intentional object — that evokes emotion. As Harré contends, "We are afraid of ..., mad at ..., jealous of ..., chagrined because ..., sad about ..., grieved for ..., proud of ..., and so on” (p. 8). Parkinson (1996) refines the construct of intentional objects and emotion by contending, "the most important objects in anyone’s environment are other people” (p. 664). The intentional objects inducing emotion include the things people say and do or "what we believe or were told that they have said or done" (Davies \& Harré, 1991, p. 44). For the most part, positive emotional responses are associated with social interactions and interactants. As Parkinson maintains, "the things that people do and say are 
typically the things that affect us most, especially if we are involved in some kind of established relationship with them” (p. 664), such as ongoing work arrangements.

Emotional responses to workplace experiences also implicate temporality (Harré, 1986; Parkinson, 1996) and are contrasting moments that "point backward and forward ... and display a relational history” and a relational future (LeBaron et al., 2009, p. 212). A key facet of the intentional objects associated with emotional assessment is the social history between and among people, a history that serves as contrast for, or evidence to substantiate, meaning-making and emotional reacting. For example, most organizational members would feel proud if they received their bosses’ or peers’ positive recognition for past work, believing that this currently positive episode could engender positive interactions in the future.

Additionally, Harré (1986) and Parkinson (1996) contend that emotional assessment draws upon and is driven by a "local moral order, ... local systems of rights, obligations, duties, and conventions” (Harré, p. 8). Systems of rights, obligations, and so forth that drive emotional assessment can also be articulated as big-d Discourse, “a rather universal, if historically-situated, set of vocabularies, standing loosely coupled to, referring to or constituting a particular phenomenon” (Alvesson \& Kärreman, 2000, p. 1133). These bases for positive assessment are the "broader cultural value systems ... [inculcated through] a background of socialized interaction” (Parkinson, 1996, p. 665). We refer to these simply as discourses and argue that these shape (among other things) what employees consider affirmative and valuable about their jobs.

Employees positively assess certain episodes and events because these experiences resonate with deeply held beliefs about what is good and bad about working. For example, most U.S. employees would be happy about being publically recognized for outstanding work because of social conventions valuing individualism (e.g., Wieland, 2006) and success (Du Gay, 1996). They would probably be pleased with better-than-average salaries and benefits because such things resolve concerns about ontological security (Giddens, 1991) and point to them as exceptionally valued 
workers. Most employees value friendly coworker relationships because they enhance interdependent work and can develop into friendships (Sias \& Cahill, 1998) and support networks (Gómez, 2009). Benefits of Positive Emotion

Empirical work on positive emotion has a rich history in psychology and a growing interest in organizational studies and suggests that positive phenomena are associated with desired organizational goals and beneficial human outcomes (Emmons \& McCullough, 2003). Compassion can provide supportive spaces for persons suffering loss as well as be "a factor in both attracting and retaining staff” (Frost et al., 2000, p. 38), and affectionate writing about someone a person loves can reduce stress hormones and serum cholesterol (Floyd, Mikkelson, Hesse, \& Pauley, 2007). High (as opposed to low or moderate) perceptions of workplace justice protect against coronary heart disease (Kivimäki et al., 2004). Positive emotions can undo the cardiovascular after-effects of negative events (Fredrickson, Mancuso, Branigan, \& Tugade, 2000) and increase longevity (Danner, Snowdon, \& Friesen, 2001). Extensive research confirms these health benefits (above and beyond any benefits to organizations) and points to social relationships as the intentional objects of positive assessment.

Research also suggests that positive affect improves creativity (Isen, Daubman, \& Nowicki, 1987) and efficiency (Grawitch, Munz, \& Kramer, 2003), broadens individuals’ scope of attention (Fredrickson \& Branigan, 2005), and increases intuition (Bolte, Goschkey, \& Kuhl, 2003). Positive emotion can enhance problem-solving (Isen et al., 1987), improve certain types of information recall (Isen \& Baron, 1991), increase efficiency in highly complex decision-making (Isen \& Means, 1983), and lead to more cooperative approaches during conflict resolution (George, Brief, \& Motowidlo, 1996). There is evidence that positive affect increases personal resources by expanding cognitive processes (Fredrickson, 1998) and improving physical and mental performance (Bryan \& Bryan, 1991). These benefits also appear to be durable: “The personal resources accrued during states of positive emotions ... outlast the transient emotional states that led to their acquisition” (Fredrickson, 
2005, p. 123), and "good feelings about the job tend to persist long after the specific events which around them have passed” (Herzberg et al., 1959, p. 63).

Other work has found associations between positive emotions and desirable social behaviors such as helpfulness (Isen, 2001), generosity (Moore, Underwood, \& Rosenhan, 1973), cooperativeness (Carnevale \& Isen, 1986), graciousness (Emmons \& McCullough, 2003), increased trust, and more integrative negotiation outcomes (Anderson \& Thompson, 2004). Amabile et al. (2005) found that positive affect (in a simple linear relationship) was associated with creativity in organizations, and Bono and Ilies’ (2006) work suggests that leadership communication infused with positive emotion spreads positive affect to followers. Additionally, a recent study of Decision Support Systems found that positive mood led to using a greater number of informational cues in the DSS and making more accurate judgments (Djamasbi, 2007).

Positive affect can have unanticipated effects, however. Although positive emotion generally increases helping behavior, persons in a good mood may avoid tasks or interactions that threaten that mood. When people feel good they want to keep feeling good (Isen \& Levin, 1972). Although positive emotions are generally associated with open-mindedness, in certain situations they may limit receptiveness to persuasive messages. If a person is already negatively disposed to another person or an idea, positive emotion may do little to promote receptiveness. Additionally, when people feel good they respond more independently and “behave as they please” (Isen \& Baron, 1991, p. 13).

Despite these qualifiers, research overwhelmingly points to the benefits of positive emotion, especially for people’s physical and psychological health and well-being. Because working U.S. adults spend so much of their lives on the job, exploring the workplace experiences likely to evoke positive emotions is of great importance. In the current study, we asked about the kinds of experiences that felt good at work. We then theorized about why employees assessed these experiences positively. The following questions guided this interpretive study: (a) What do U.S. 
workers identify as their "best experiences at work"? (b) What systems of meaning or discourses inform positive assessments of organizational experiences?

\section{Method}

\section{Sample and Measures}

We gathered data using an online survey, drawing U.S. workers through online advertisements and StudyResponse ${ }^{1}$, a paid sampling service. StudyResponse sent email messages with an embedded survey link to individuals who volunteered to participate in social research. We requested an equal sampling of men and women working in the United States. StudyResponse contacted 5,000 persons and conducted two follow-up contacts at 7 and 14 days. Online search engine ads ran for six weeks during the same time frame, offering incentives for survey completion (Amazon gift certificates). Sampling resulted in 2,846 U.S. workers responding to the survey; 2,421 came from Study Response (48.4\% response rate) and 425 from online advertisements. Of the sample, 897 (31.5\%) completed the open-ended question analyzed in this study, 598 women, 272 men (27 sex data missing). Mean age was 39.5 (SD 7.8) and ranged from 18 to 69. Respondents worked in 14 occupational fields including management-administration ( $\mathrm{n}=120)$, education-library ( $n=86)$, health-safety $(n=83)$, financial-insurance $(n=68)$, technical-communications $(n=57)$, retail-wholesale $(n=55)$, service $(n=53)$, government-nonprofit $(n=47)$, manufacturing $(n=46)$, hospitality-tourism $(n=28)$, child care $(n=26)$, consulting $(n=25)$, law-legal $(n=23)$, constructionmining-agriculture $(n=22)$, and other $(n=114)$ (missing occupational data, $n=44)$.

We inquired about a variety of workplace experiences and specific to the current study asked in an open-ended format: “Please describe your best workplace experience.” We prompted respondents to provide as much detail as possible. The open-ended format allowed respondents to describe positive experiences and expand on these to whatever degree they wished. Best-experience responses resulted in 73 single-spaced pages of data. Responses ranged from a single phrase to extended paragraphs (10 - 15 sentences), averaging three to four sentences. 
Analysis

The data were subjected to grounded analysis rooted in workers' experiences rather being sensitized by peripheral schemas. We analyzed the data in two stages using an adapted form of Charmaz’ (2001) grounded approach to open coding. In the first stage of analysis, we collectively conducted open coding using a constant comparison method of best-experience to best-experience and inductively developing categories. Working together, the research team went through a quarter of the data, discussed the character and type of each positive response, and created a name and descriptive memo for it. We continued working collaboratively until we stopped finding new types and then divided the remaining data and individually coded it using the developed types.

We independently coded about a third of the data (the same third) and then calculated Scott's pi for inter-coder reliability, which was 0.79 , indicating substantial agreement beyond chance. We reconvened to discuss the data we coded differently and resolved those differences through extensive discussion coupled with reexamination of the raw data and the positive-type memos. We either found agreement or recognized that the response represented multiple types. We resolved all disparities through this process and subsequently arrived at 17 positive-experience types (see Table 1). Of the 897 response, 63 were too vague to categorize so were dropped from further analysis (e.g., "going to work each morning,”). The final analysis reflects the experiences of 835 U.S. employees.

The second stage of analysis combined the process of axial coding with theorizing the range of underlying discourses. To develop the discourses, we drew together several theoretical threads from literatures crossing multiple disciplinary lines (e.g., organizational communication, businessmanagement, psychology, sociology, etc.). One at a time, we revisited each positive-experience type and, as a research team, discussed potential answers to: "What underlying system of social meaning appears to drive the positive assessment of this experience?” We extensively discussed each experience type, revisited definitions and raw data, and discussed various literatures to clarify our understanding of and thus categorize positive-experience types. That is, we spent considerable time 
working to "see underneath" the explicit vocabulary of the exemplars to theorize about the implicit discourses likely to drive positive assessment.

Discourses served as axial codes because they provided connections between and among best-experience types. The process was true to conventions for qualitative data analysis in which researchers create axial codes that encompass a number of open-codes (Lindlof \& Taylor, 2002). Through this process, we ultimately came to an agreement that the positive experiences typified five discourses: (a) individualism-uniqueness, (b) power-empowerment, (c) success-accomplishment, (d) belonging-connection, and (e) safety-security. Table 1 summarizes these discourses and the associated positive-experience types. In what follows, we expand on the theoretical discourses and the experiences they encompassed.

Insert Table 1 about Here

Findings

To this point we have implied that positive experiences led to positive emotions without explicitly making the connection. Data did substantiate this move, however; responses left no question regarding the connection. In most cases, respondents specified their positive emotional responses (emphasis added): "When my boss told me I was irreplaceable and that she would like to have about 10 of me, that made me feel good." "It made me happy that they felt I knew the job well enough and that I could help teach someone else.” "I have been at this new job for just over a month, and I feel good about it already,” “That makes me feel good to know I'm doing a good job.” “Getting all my work done and feeling pride in it." "I feel there is a purpose to my job.” In some cases they implied positive emotional responses: "I currently am allowed to work from home 2-3 days a week, and this is great!!!" "It was a wonderful experience to be able to achieve my potential.” "Our 'fun time' at work, even if it is only a quick comment that makes us all laugh, is absolutely wonderful."

A few other issues bear mentioning. Although presented as a fixed typology, the experiences represent communicative transactions and processes stretching over time. The temporal feature of 
positive experiences was evident in most responses. The following comment from a 39-year old woman in the telecommunications field is illustrative: "My best workplace experience was when I landed a huge deal for our company. For the following few weeks, people would mention my prior success” (emphasis added). Also, positive experiences were social and deemed so in relation to intentional objects (peers, managers): what others were thinking about respondents, what others said to respondents, what others did that helped or reflected on respondents, and so forth. This comment from a 54-year old man in public safety demonstrates the social features of positive experiences: "I was voted Employee of the Year several years ago and appreciated the support and encouragement from all that helped me fulfill my job responsibilities.” Many responses also traversed positiveexperience types and discourses. The following 42-year old woman's experience illustrates this feature of nearly all responses:

I worked as an Executive Secretary for a Vice President of a hospital. He appreciated me and other people [appreciation, Individualism] and we all liked each other, went out after work with just friendship [relationships, Belonging], and this was a nice environment [climate, Safety] and place to work with good benefits and salary [resources, Security] and he made things better by being a nice person to work for [supervisor, Safety].

So although we have taken apart responses in order to analyze the discrete components of experience, intact responses usually represented multiple positive experiences and discourses. In what follows, we describe each discourse and present the positive experiences typifying it, using exemplars for illustration. We include the number of positive experience types to illustrate their relative frequency (see Table 2).

Insert Table 2 about Here

\section{Individualism-Uniqueness}

The ideology of individualism stresses the inherent worth of the individual, free choice, and self-determination, and centers meaning, responsibility, and worth in the self as opposed to the social group or circumstances in which the self exists (Wieland, 2006). As Taylor, Flanagin, Cheney and Seibold (2001) have argued, organizational life is often structured around "modern Western 
conceptions of the individual that stress autonomy, uniqueness, and agency” (p. 112). In most U.S. workplaces, rewards or punishments, acknowledgements or social ostracism, and overcoming challenges or failure, are targeted toward individuals. Although this stands in stark relief to the literally interdependent character of work, employees often strive to exceptional in comparison to others (Bellah, Madsen, Sullivan, Swidler, \& Tipton, 1985).

The experiences underscoring individualism-uniqueness were deeply and inescapably social, including others' recognition of the respondent as special, standing out in the crowd, and being positively different from others. This discourse was by far the most frequent (454 responses) and typified by appreciation, what others implied about respondents, recognition, others’ directly verbalized praise others about respondents, and reward, tangible items others gave to respondents for exceptional performance. In these experiences, the intentional objects of emotion were episodes of others’ positive feedback and social responses to respondents’ performance.

Appreciation indicated feeling valued by others, but without articulated recognition or material reward (81 responses). Feeling appreciated included having others indicate that respondents were valued, respected, esteemed, and so forth. For example, a 38-year old man in public safety reported, “I was in a job where I was given a lot of responsibility. My boss was on paternity leave, and he asked me to take over a lot of his daily work. I felt complimented and respected.” Feeling appreciated was a positive emotional response to the boss' trust. Such appreciation was also evident in an response from a 30-year old woman in insurance:

I was able to make a huge difference in day-to-day operations by creating a suite of tools that were outside of my job description. I did not receive any financial or professional recognition for this project (no raise, no promotion), although supervisors were well aware of this contribution and its effects, but my coworkers at the same level were very appreciative.

In these experiences, employees sensed others' special attention that marked respondents as positively distinctive from others. Even without material reward or public recognition, others’ appreciation resulted in elation, pride, and gratitude. 
Recognition was the most frequent experience evoking positive emotion at work (236 responses). We coded only those experiences in which others orally articulated positive feedback to respondents, either privately or publicly. These responses included being "praised for a job well done,” “told I am fun to work with,” and “told I was a very valuable person.” Recognition made workers feel interpersonally significant, needed, unique, and particularly successful. Some responses contrasted positive feedback with its absence in other jobs. As a 32-year old woman working in a Tupperware distributorship explained, "My manager calls at least once a week to encourage; her supervisor sends out emails of 'personal thanks' to members under her. All of this was unheard of in my previous distributorship.” The manager’s ongoing encouragement was a marked change from this woman's past working environment and positive because of the contrast.

Public praise was also part of recognition in some cases. A 54-year old man (occupation unspecified) reported his best job experience was "being singled out for doing my job, going above and beyond what was expected of me, in front of my colleagues.” An exceptionally moving story of recognition came from a 37-year old woman in health care:

The highest honor I have ever received in my life is when, at the end of a company dinner held in his [her boss'] honor, he and his family all came up to me and each in turn performed "namaste" [a reverential greeting] with the very low bow, which is done only for a mahatma, a "great soul.” I felt I did not deserve that honor, but they insisted. I am truly lucky to have worked for such a wonderful, caring person.

In all cases, recognition underscored the relational, social character of emotional responding in organizational life in ways that highlighted respondents' unique value.

Reward included experiences in which others presented respondents with something material to commemorate their unique contributions (137 responses). These included (a) bonuses: “when I get a bonus check for doing a job well done,” (b) promotions: “being promoted to team leader,” (c) trips: “won an all expense paid trip to Las Vegas,” (d) honoring parties: “I was recognized with a party for my 20 years at the company,” and (e) awards: “winning international award for project.” In some cases customers provided monetary rewards: “working as a cashier and getting a \$500 tip.” Reward 
and recognition typically co-occurred ("I was recognized in our meeting with kind words and given an award at work.”). As with appreciation and recognition, rewards distinguished respondents within the workgroup. Being so distinguished supports Harré's (1986) and Parkinson’s (1996) argument that positive affect occurs in relation to intentional objects, in these cases, coworkers and their reactions to respondents.

\section{Power-Empowerment}

Organizations are, among other things, webs of political relations in which networks of power, control, and resistance are continually forming and reforming (Mumby, 2001). Organizational members typically want to be central in the webs and connections symbolizing power. Mechanisms of power are embedded in historically, culturally situated discourses (Foucault, 1972) and systems of meaning (Harré, 1986), and evoke positive emotional responses when power is "held” momentarily due to particular experiences or interactions (Anderson \& Thompson, 2004). Within this discourse, positive affect can occur in response to two related experiences: feeling empowered (Bloch, 2001) and empowering others (Gomez \& Rosen, 2001). In the current study, the discourse of powerempowerment was exemplified by these two types of experience (170 responses) and included voice, autonomy, flexibility, and altruistic work.

Voice included being able and free to offer opinions or ask questions and having others solicit respondents’ opinions regarding important issues (30 responses). Voice also included feeling heard or needed by others, such as when others attended to or acted on respondents’ input. Feeling heard was evident in an response from a 27-year old woman in the transportation industry:

I coordinate a regulatory committee here and the committee members treat me as not only a member (though I am not a member), but look to me for advice and ideas. I'm soon going to retire, and dozens of people I deal with have said how much they'll miss me and the excellent work I do.

Others depended on this woman for ongoing work processes, despite her lack of formal position. Other examples were, “my opinions are always taken seriously,” and "I have an active role in 
everyday decisions.” Certain responses illustrated a contrast regarding positive experiences: A 31year old woman in law enforcement said, “As a part-time employee in an industry that doesn't respect part-timers, I'm allowed to attend meetings, conferences, make decisions on how money should be spent.” The intentional object was how others with her status (part-time) were typically treated and how her treatment from others contrasted with this norm. In many cases, voice was indicative of power—saying something and having others listen and then act on what was said.

Experiences labeled autonomy were those in which respondents worked independently and self-supervised, a condition granted by formal authorities (85 responses). Autonomy included being able to carry out tasks as respondents saw fit and working with little or no direct supervision, working arrangements that implied having others’ trust. A 33-year old woman (occupation unspecified) reported that her best work experience was "being able to do my job and make decisions without having to have approval from anyone else.” Similarly, a 42-year old woman in customer service said, "when my boss was on vacation and I was left completely to myself to do my work in peace.” The absence of oversight and micro-management was an undercurrent in autonomy; many respondents valued work arrangements where they were their own boss, so to speak. Autonomy gave respondents personal power, independence, and freedom.

Flexibility experiences were those in which tasks, goals, or work arrangements were adapted to workers' desires or needs (22 responses). Respondents typically described flexibility in relation to the demands of their non-work lives. A 33-year old woman in finance shared that the "schedule was modified so I could work more from home with new baby. (Not easy in my line of work).” Her positive response to the accommodation came from contrasting it to a professional norm. In this case, flexibility implied unique, special treatment, something arranged and granted expressly to her (also implicating individualism-uniqueness). A 65-year old man in marketing described his gratitude for flexibility during a time of need: "When my daughter was very ill and needed to be hospitalized, I was able to take the extra time off that I needed with no penalty.” Being given the flexibility to 
manage job arrangements symbolized power and control, even though paradoxically, others usually granted the flexibility. Despite this paradox, when work was flexible and workers could shape working around their needs, their responses implied a sense of authority and prerogative over more aspects of worklife, especially those that stretched into private spheres.

Altruism and altruistic work was doing one's job in a way that empowered or improved the lives of others (33 responses). These responses included helping others via education and life-skills training or improving others’ feelings. A 25-year old woman in social services shared, “The satisfaction in my heart that I am able to make a difference, however small, in senior's lives.” Similarly, a 26-year old woman in retail reported helping "comfort a young girl who broke her leg in my store” as her best work experience. With voice, autonomy, and flexibility, others typically bestowed these on workers. Altruistic work shifted this balance, and respondents bestowed power in a general sense to others. Thus, empowering others suggested personal power and underscored the idea that “power is not an inherently noxious phenomenon” (Giddens, 1984, p. 32).

\section{Success-Accomplishment}

Success and accomplishment spring from a number of discursive meaning systems and ideological themes in U.S. workplaces. The American Dream beckons, promising opportunities, encouraging hard work and diligence, and emphasizing the power of the individual to create his or her own destiny. First articulated in the New Deal of the 1930s, this ideology paints U.S. America as “the land of opportunity in which any individual, through hard work an self-improvement, can become a success” (Guest, 1990, p. 390). Meritocracy, a closely related idea, advocates accomplishment and advancement based on individual achievement rather than royal birth, wealth, or social position (Son-Hing, Bobocel, \& Zanna, 2002; Young, 1961). Closely associated is the notion of the enterprising subject, the worker who finds personal fulfillment and meaning from the act of working and as a result, fulfills corporate goals without the need for corporate management. In 
capitalistic societies, the enterprising worker can even be held up as a moral icon, especially if the drive toward economic goals becomes a matter of national pride (Du Gay, 1996).

Experiences typifying this discourse echoed these interrelated ideologies and included challenge, success, and opportunity (148 responses). Heroic stories of attainment, reaching goals, and overcoming obstacles marked this discourse. Respondents said that personal achievement evoked pride, satisfaction, and excitement. Although experiences were individual attainment, in nearly all cases respondents pointed to others’ perceptions as key to their own positive assignment of meaning to the experience.

Success was the completion of tasks or projects that created a source of pride or proved wrong persons who had doubted the respondents' abilities (80 responses). A female student (age unspecified) explained, "I had a presentation and everybody loved it and my adviser was full of genuine praise.” A 42-year old man in manufacturing said “[I] installed a new computer system and trained my group of planners to work out the kinks of this system in 2 months. It was a huge success and great learning experience.” Several contrasted their success with someone's forecast of their failure. A 45-year old man in construction reported:

When I started working here I did not know all of the requirements for my job. He knew that in the interview. When it came time for me to do that part of my job, he told me that I would have to learn it myself and that I misrepresented myself when I was hired because he thought I knew how to do that aspect of my job. I told him I would make him eat his words and I did.

Several others respondents’ best work experiences specified an intentional object—someone’s negative prediction — they believed they had “proven wrong.” Overcoming others' predictions of failure evoked pride and a sort of gritty victory.

Opportunity involved favorable combinations of circumstances, time, and place that both expanded job responsibilities and positioned respondents for advancement (58 responses). These included being specially selected for responsibilities, given the chance to make important decisions, and provided with a professional opening for extending knowledge and expertise. Selection for 
special opportunities prompted feelings of pride, happiness, and self-respect and provided the time and place in which to work beyond their current job descriptions. As a 28-year old woman in consulting explained, "I was asked to perform in a training video, because of my work habits and outgoing personality.” Other opportunities included being given special authority or responsibility allowing them to demonstrate their abilities. A 44-year old woman in administrative support reported: “Two weeks into the job, my HR manager/supervisor having enough confidence in my knowledge and abilities to let me solely make hiring decisions for the 300+ employee company.” Exciting new chances for success constituted opportunity, experiences that made jobs "much more enjoyable and prestigious,” and evoked pride, excitement, and enthusiasm.

Challenge was experiences in which respondents overcame obstacles in particularly demanding circumstances (10 responses). One exemplar was accurately reporting a robbery at work to the police; another required the respondent to overcome language and cultural barriers. In the latter, a 39-year old man in manufacturing said, "being able to develop strong personal relationships with my staff in Korea despite the large cultural and language barriers has been very rewarding.” Still other responses highlighted overcoming environmental and human obstacles such as equipment failures, looming deadlines, and ineffective coworkers. For example, a 23-year old woman in banking said, "I would say the day I kept a critical piece of equipment in the building from overloading; everyone was so grateful that I could come through.” These experiences were inherently social and transactional; respondents surmounted problems and others reciprocated with gratitude.

\section{Belonging-Connection}

The discourse of belonging-connection underscores the importance of affiliation in organizations. That this emerged as a central guiding discourse (second only to individualismuniqueness) calls direct attention to the interdependent, social nature of organizational life (Gómez, 2009). Work environments are more than simply places where people gather to complete tasks, they are social arenas replete with emotional dramas (Fineman, 2008). Organizational members make 
friends (Feeley, Hwang, \& Barnett, 2008; Sias, 2005), give and receive social support (Gómez), and even cultivate budding romances (Horan \& Chory, 2009) at their jobs. Belonging-connection identified human connections as best work experiences, articulating the importance of social embeddedness through relationships, social support, and teamwork (267 responses). These experiences were positive because contact with others enriched respondents’ work or personal lives.

Relationships indicated connections with coworkers (i.e., anyone with whom respondents worked) such as friendships, romances, great working relationships, and social events (186 responses). The importance of workplace relationships was striking; only recognition exceeded the frequency as a best-work experience (see Table 1). Some reported friendships that had developed at work, as did a 45-year old woman in education: "I love when the coworkers hang out with each other outside of work, because many of us are not only coworkers, but friends as well.” Some used a family metaphor to describe their best experiences at work: “The last place I worked was like working with family; even my boss and I were very close.” "Currently I work in an organization [where] we truly feel like we are part of one big happy family." "Everyone is like family, we may fight sometimes but we always make up.” These respondents said their best experiences were social events such as "pot-lucks,” "holiday parties,” "surprise birthday party,” and "hanging out” with coworkers. They indicated that social relationships at work made them feel "part of,” reporting feelings of “belonging,” “joy,” “love,” “gratitude,” and being “blessed.” Such responses reinforced Parkinson’s (1996) argument that “the most important objects in anyone’s environment are the people, ... [and that] other people are one of the most common causes of emotion” (p. 664). Social support included experiences in which coworkers offered two types of encouragement or help: emotional support and instrumental support (26 responses). Emotional support was personal, psychological help, typically offered in response to happy events (birth or adoption of a child) and unhappy events (hospitalization, divorce, family member death). Coworkers responded to triggering events, those “critical situations in which routines are radically disrupted” (Giddens, 1984, p. 41). As 
a 50-year old male teacher related, "When I had a death in the family, I received sympathy and support from the whole school.” Coworker compassion was momentous. Instrumental support provided for accommodations such as sharing workload and granting flexible schedules or time off, which eased unhappy life events. Emotional and instrumental support typically co-occurred. For example a 30-year old woman's best experience was “When I worked for a large utility company, I was going through a divorce. Everyone, including my supervisors, supported me emotionally and with work schedules, so I could go to court and deal with other matters.” Social support deepened respondents’ connections with their coworkers and, at times, employing organizations. When respondents really needed help, they were "moved” and "grateful” that coworkers stepped up.

Teamwork included experiences in which respondents worked collaboratively and successfully with coworkers toward a common goal (55 responses). Respondents described more than simply completing a complex difficult task, they also described emotional elation and connection. These workers described their experiences with terms such as "team spirit," “very satisfying,” "it all came out wonderful,” "pulling together," “support and camaraderie,” and "taking each others needs into consideration.” Teamwork engendered feelings of affiliation and belonging and was particularly important when respondents faced tasks requiring joint effort. For example a 37-year old woman in the health industry said, "several times we were very busy with pressing deadlines and our entire team came together to get the job done by our deadline.” Working together meant feeling part of a collective by committing to and accomplishing something that could not have been done alone. Collective commitment was a key theme in teamwork and appeared to be socially contagious. Safety-Security

Paid work satisfies basic needs so is inextricably bound to humans’ drive for ontological security, a "sense of continuity and order in events” (Giddens, 1991, p. 243). Organizational life is also significant to preferred self-identities, which themselves are built on "confidence or trust that the natural and social worlds are as they appear to be, including the basic existential parameters of self 
and social identity” (Giddens, 1984, p. 375). The beliefs necessary for ontological security are part of the reason employees develop psychological contracts with employers. The "beliefs employees have about the entitlements they will receive and that they perceive were promised to them by their employers” (Hamel, 2009, p. 235) comprise these virtual agreements and include issues such as “long-term job security, career development, and sufficient power and responsibility” (Hamel, p. 235). Certain kinds of positive events fulfill these unspoken obligations, experiences we categorized as safety-security. In many cases, best-job experiences were organizational arrangements that went beyond basic expectations and enhanced feelings associated with ontological security.

Safety-security centered on experiences that made respondents feel especially protected, comfortable and stable, free of fear, and safe from negative events (198 responses). Responses typically included “safe,” "relaxed,” “supportive,” “positive,” "healthy,” and “open” when describing working environments. In these environments, people were friendly and caring, communication was fair and respectful, and organizations provided notable resources. At times, safety-security included prevailing over particularly negative episodes and emerging triumphant. The positive experiences typifying this discourse were climate, supervisor, resources, and triumph.

Climate included experiences of working in environments identified by openness, honesty, and encouragement (62 responses). Illustrative expressions included “a place where you feel at home,” "an overall positive working atmosphere,” "everyone was comfortable with each other,” and “it is a safe place to work.” Respondents depicted positive climates with reports of superiors and coworkers easily conversing, showing mutual respect, and treating each other as equals. Voice was woven into many climate responses: "I am able to communicate honestly and openly with my boss about concerns.” Overall, positive communication climates engendered feelings of wellbeing and were evident in descriptors such as "positive and healthy,” "giving,” “comfortable,” “supportive and inclusive," "fun and caring,” and "caring and compassionate,” among others. Respondents often linked positive climate and good feeling with supervision. 
Supervisor/mentor included generally working for a great boss and specifically outstanding supervisory acts (77 responses). Many underscored voice and equality in supervisor-subordinate communication: “encourages me to ask questions," "able to give input on an equal level," "considers me an equal and values my opinion," and "treated everyone from the President of the company to the trash collector the same.” Respondents often reported communication encouraging voice, highlighting equality, and demonstrating respect. Responses included reports of supervisors who cared about respondents' welfare: "I was under the weather and the boss told me to take care of myself," encouraged input: "My boss encourages me to ask questions and if I have to re-ask them, it is ok. I finally feel respected and not intimidated,” and provided exemplary role models. A 40-year old man in the hospitality business reported:

I had a boss who took me under his wing when I was 18 \& taught me the ethics of work. Often hard, but ALWAYS with respect. He treated me as an equal \& I did become the MASTER BAKER he wanted me to be. Here it is 30 years later \& we still see each other \& admire each other just as much if not MORE then we did then. All because he treated me the way he wanted to be treated I worked harder for him then anyone else EVER. Money never mattered as long as I got to work along side of EGON—my MENTOR!

Great bosses evoked gratitude and a sense of security. When supervisors took employees under their wing, respondents reported greater loyalty, trust, comfort, and calmness. Positive leader-member communication was crucial to stability at work and stood out as particularly wonderful experiences.

Resources marked experiences involving notable materials, compensation, information, and so forth that eased work and increased chances at success (44 responses). These positive experiences involved, among other things, tools and materials: "able to obtain all the materials and tools needed to do a proper job," compensation: "had lots of employee fringe benefits—paid company ski trip, 100\% covered health care, good salary,” information: "all the information I needed to complete the deal was there on time and in the correct order,” and work distribution: “everyone does equal amounts of work.” Respondents associated excellent resources with security and achievement because they reported having the raw materials necessary to do exceptional work. 
Triumph were experiences in which the absence of a negative dynamic or person comprised the positive experience, especially when negativity threatened well-being (10 responses). These dynamics exposed employees to destructive interactions and disturbed perceptions of long-term job stability. Some explained that merely the absence of an abusive supervisor constituted their best experience. Examples of the relief when a negative situation ended included, when the "boss was not around,” "the days I have to work and my supervisor is gone!,” and “when my incompetent boss retired.” A 39-year old woman in public safety explained that seeing her superior fired was her best work experience: “in the end, seeing her 'unappointed,' I can say I persevered and outlasted her, and that I was right in the end.” This response also implied success. Overall, triumph over negative situations increased positivity by making the workplace less threatening and affording vindication.

\section{Discussion of Implications}

Positive-work responses have a number of key implications regarding the (a) study of positive emotions at work as interactional, (b) link between work dynamics and ontological security, and (c) linguistic dialectic of presence and absence. Each of these implications points to analysis at a different level. First, the communicative character of positive emotions at work explores the implied micro-processes embedded in exemplars. Second, at the level of ontological security, we move back from the details of workers' experiences and take a broader view of what the interpretive discourses have in common. Finally, the presence-absence dialectic represents a mid-level analysis of certain data segments that demonstrates a chronically produced linguistic pattern.

\section{Positive Emotions at Work as Social}

Findings in this study confirm past theory arguing that emotions are social (Harré, 1986; Parkinson, 1996), even in the goal-oriented arena of the workplace (see also Waldron, 2000 for a discussion of relational emotions at work). At work positive emotion comes about due to ongoing interactions with coworkers, customers, and clients. Responses are replete with social indicators: "Working with people that respect my thoughts \& feelings.” "I worked with a manager who was very 
similar to me for about 6 months. She often appreciated me vocally, both one-on-one and in team meetings.” "They are giving me their best, and I reward them with the same as far as employer/employee situations go." "I'm soon going to retire, and dozens of people have said how much they'll miss me and the excellent work I do.” These exemplify acceptance, positive affirmation, reciprocity, and friendly relations. Assessment of positivity is intersubjective and involves mutuality among a number of people: "We are a cohesive group that truly enjoys each other." "We were all equal and everyone felt it.” "I like everyone in my group (people I supervise as well as my supervisor), and we have had great interactions for the past several years together.” Thus, findings demonstrate that "emotions result from real, anticipated, imagined, or recollected outcomes of social relationship” (Kemper, 1978, p. 32 emphasis original).

Assessment of positivity is also transactional and dynamic, emphasizing the "reciprocal, bidirectional influence of the communication environment, the responsiveness of communicative partners” (Wetherby, Warren, \& Reichle, 1998, p. 2), and mutually constitutive character of human interactions over time. People at work are simultaneously the sources of messages and actions monitored by others (coworkers, customers), interpreters of others' messages and actions, reflectors of their perceptions of others to others, receivers of others' perceptions of themselves, and reflexively monitoring actors who fashion communication and make meaning in a recursive manner (Giddens, 1984). One aspect of transaction came from a 27-year old woman in accounting who reported:

A previous employer would take the time to ensure that I understood exactly what had to be done, and how to do it. If there was an error to be made, he wished it to be his and not mine. I try to follow the same method for training.

Her experience illustrates one aspect of the mutually constitutive dynamics in transactional experiences. She was first the recipient and later the source of positivity. She perceived her boss as someone willing to take responsibility for mistakes (as opposed to blaming her). Each of them contributes to positive meaning: the male boss models and the female employee interprets and subsequently imitates the positive model. 
Additionally, positive assessment is bound to social cues, in most cases others' enacted perceptions of the respondents. Evidence of this in our data included: “dozens of people have said how much they'll miss me and the excellent work I do," "She said that we made her job easier," "when my manager ... said she was glad to have hired me," "he said I was very important to the company," and "people would mention my prior success and it was reported to upper management." Throughout the best-work examples we found that people feel good about their jobs when others reflect a preferred self-image back to them in positive ways. Quite simply, positive emotions are social; they are about and in response to other people.

\section{Positive Experiences and Ontological Security}

Taking a figurative step back from the data, we find an overarching connection among the discourses that suggests positive experiences have broader implications than making people feel better temporarily. This connecting thread is a drive for ontological security, the "confidence or trust that the natural and social worlds are as they appear to be, including the basic existential parameters of self and social identity” (Giddens, 1984, p. 375). Positive experiences of all types and under all discourses illustrate the human need "to develop or sustain trust in [their] own self-integrity" (Giddens, 1991, p. 54). The drive for ontological security is a connection embedded in the discourses of belonging, success, safety, power, and even individuality.

Workplace experiences have particular importance for ontological security because so much rides on what happens at work. In fact, all the human needs Maslow (1943) imagined can be met by aspects of work and working. Compensation satisfies basic needs for food and shelter; thus, survival depends on positive workplace performances. As the United States lacks universal health care, joblinked benefits provide for employees' health and the health their families. Benefits also stretch across time and space to lay the foundation for meeting the basic needs of retirement. Work provides vital material for subjective identities, and separating what a person does from who a person is, is increasingly difficult (Buzzanell \& Turner, 2003). Human connections form at work, and work can 
serve others and aid the common good. Overall, the experiences respondents report as their best involve self-perceptions of how good and worthy they are as persons, how valuable, how esteemed, or how desired in this important context.

Positive experiences indirectly buoy up organizational members, protecting them against perceptions of employment and identity loss. If others recognize employees' excellence and they stand out in the crowd, this bolsters job security. Control and power over work arrangements implies others' trust and faith but also contributes to career capital, the proficiencies that employees hold as assets in job market bargaining and negotiation (Suutari \& Mäkelä, 2007). Building strong bonds with others in the form of friendships or tightly coupled work interdependencies, to some extent ensures embeddedness in organizations. Having the time and resources necessary to do a good job supports success, which makes employees more valuable to the organization, and thus (hopefully) insulates them from economic loss and protects preferred self-identities. Clearly, much is at stake in terms of "the basic existential parameters of self and social identity” (Giddens, 1984, p. 375).

\section{Dialectic of Presence and Absence}

At the level of language use, employee responses chronically reproduce a linguistic pattern of presence and absence, a pattern apparent in rhetorical perspectives of language. Adorno (1973), for example, explains the pattern of contrasts we found in segments of our data. In Negative Dialectics he notes, "the indirectness of something direct is a reflexive determination that makes sense only in regard to its opposite, the direct thing” (p. 171). Similarly, Fazio (1987) describes the dialectics of presence and absence "when the absence of a feature serves as the positive signal” of something desired (p. 136). Derrida (1974) also indicates that when describing subjective experience, it is often difficult to define something without invoking its opposite.

The assessment of positivity often involves casting forward and backward to draw distinctions between positive and negative experiences. The presence-absence dialectic also compares positive experiences with others' experiences deemed less fortunate. The example of a 
part-time worker's inclusion in processes in which part-time workers are not typically included implies contrast with those less fortunate. In some cases, best-work experiences contrast to oblique or implied subject matter. In other cases the presence-absence dialectic is explicit, and the absence of a negative is the positive. For example, "My best [job experience] is now. I left the previous job; now I work for a church where people do care.” This implies, where I worked before, people did not care. Similarly "Walking out at my last job!!,” because of the double exclamation points, implies: I am exclaiming (!!) that leaving my last job was my best workplace experience. Further oblique content is: I am proud of leaving my last job. This response, then, evokes individualism, power, and success.

The exemplar, "When my boss was on vacation and I was left completely to myself to do my work in peace,” leaves unstated what conditions were like when the boss was present. The response implies, however, when my boss is around, I do not work in peace. Another contrasting experience, “A supervisor that continually made work twice as hard for everyone because of his unwavering idiocy was finally fired," states that work was difficult and trying prior to the supervisor's firing. The response implies, however, victory and even revenge, suggesting that positive assessment can at times be somewhat perverse. In these ways, absence and presence work by contrasting the experience to negative personal experiences or others' who do not have it as good as the respondent.

\section{Limitations and Future Directions}

The study is not without limitations, some of which suggest areas for future study. Our approach emanates from a philosophical belief that positive experiences are desirable in organizations. Indeed, we have had and have enjoyed many peak moments in our jobs. Despite what is likely to be read as somewhat prescriptive due to our philosophical stance, evoking positive emotions may not always serve organizations or their members. For example, someone in a good mood will often interact with others in ways that protect that mood. That is, people feeling good can be less inclined to help others in need or deal with unsavory but necessary tasks if doing so will ruin their good mood (Isen \& Baron, 1991). In organizations serving disadvantaged persons (e.g., 
homeless shelters, alcohol treatment) this could pose problems. In situations where confronting employees’ destructive communicative tendencies is necessary, positive affect might be adversative.

Additionally, “under certain circumstances positive affect may promote a sense of personal freedom, and people who are feeling good may act more in accord with their own wishes and principles than at other times” (Isen \& Baron, 1991, p. 15). When organizational goals require close adherence to rules, procedures, and conventions, such independent thinking could cause problems. Hoschild's (1983) account of emotion labor required of bill collectors, which involves pejoratively framing persons delinquent on their bills, is a setting where encouraging positive affect might be counterproductive to organizational goals. In other words, there can be drawbacks to positive emotions at work. Future research might explore these positive and negative potentials.

Another issue is data collection; respondents word-processed their responses, which we believe presented three issues of concern. First, typing in responses likely shortened responses due to the effort required. Answers were all quite short, and this is likely part of the reason. Brevity assisted analysis, however, as positive experiences came to us already unitized, so to speak, and did not require extrapolation from extended transcripts that might have reduced clarity. Second, the survey approach did not allow follow-up questions, which was problematic for understanding responses too vague to categorize (e.g., “every day I go to work”). The open-ended survey format did, however, allow gathering responses from hundreds of U.S. workers, something less than feasible if done in one-to-one interviews. Finally, self-report data were likely subject to the recency effect in which the experiences freshest in respondents’ minds were most salient (Steiner \& Rain, 1989) and thus reported, rather than culled from entire work histories.

The current study suggests other areas for future study as well. Our typology lays the groundwork for developing a standardized measure of positive workplace experiences. The development of a scale to ascertain positive experiences could be useful for better understanding the global trends for U.S. workers and assessing experiences likely to evoke positive emotion and 
improve specific organizational environments. Since most of the positive emotion research is experimental, tools for measuring positive experiences that spontaneously occur in organizational settings could assist in the transferability of this research to applied settings.

Another area for future study implicates sample demographics. Although the sample represented a wide range of occupations, future study might consider how sex-gender and occupation influence perceptions of best-work experiences. For example, certain professions value some experiences over others. In sales, for example, relationships with coworkers might not be as positively assessed as reward or overcoming obstacles. We did report the age, gender, and occupation for many exemplars to provide a sense of these differences but did not systematically analyze demographic particulars. Such an exploration would be fruitful in future research.

\section{Conclusion}

The current study extends contemporary understanding about workplace that evoke positive emotion. Researchers and organizations can use this information to more constructively organize work and organizational life. We also illustrate workers' instantiation of the social meanings or discourses engendering positive assessment. These systems of meaning likely inform all workplace experiences—-positive, neutral, or negative—so can provide a functional heuristic for understanding a variety of organizational phenomena. 


\section{Footnotes}

${ }^{1}$ The StudyResponse project is a paid sampling service of Syracuse University, facilitates sampling for many university studies and, as such, is not a collaborator or subcontractor in this study (StudyResponse disclaimer). The service simply sends an electronic message with a link to the study’s online survey posted with Survey Monkey to respondents who have agreed to participate in online social science research. As an incentive, respondents’ names are placed in a drawing for gift certificates from Amazon and other online retailers. The service protects respondent identity; respondents are identified by a unique, anonymous ID, which they enter when beginning the survey. For an in-depth explanation of the sampling service, see studyresponse.com. 
Table 1: Discourses and Positive-Experience Types

\begin{tabular}{|c|c|}
\hline Discourse & Positive-Experience Types \\
\hline Power- empowerment & $\begin{array}{l}\text { Voice: having voice, feeling heard, action taken based on } \\
\text { someone’s speaking up/out } \\
\text { - Autonomy: ability to work and make decisions, independently } \\
\text { - Flexibility: work arranged around needs of worker } \\
\text { - Altruistic work: task/work is intrinsically rewarding and positive } \\
\text { through one's ability to affect change in the lives of others }\end{array}$ \\
\hline Individualism-uniqueness & $\begin{array}{l}\text { - Recognition: Verbal acknowledgment (not material reward) } \\
\text { - Appreciation: Feeling valued by others without explicit recognition } \\
\text { or reward } \\
\text { - Reward: Material award or bonuses acknowledging person }\end{array}$ \\
\hline Success- accomplishment & $\begin{array}{l}\text { - Challenge: meeting, overcoming a challenge difficult task } \\
\text { - Success: successful discrete task completion as source of pride, } \\
\text { also proving others wrong with success } \\
\text { - Opportunity: special opportunity, being allowed or encouraged to } \\
\text { expand job responsibilities, being positioned for advancement, } \\
\text { promotion }\end{array}$ \\
\hline Belonging-affiliation & $\begin{array}{l}\text { - Relationships: connection with people at work (e.g., friendships), } \\
\text { social feelings at work with others, social activities with people at } \\
\text { work } \\
\text { - Social support: receiving needed help and encouragement, } \\
\text { especially in times of adversity and need } \\
\text { - Teamwork: working collaboratively with others toward common } \\
\text { goal, especially when teamwork is marked by commitment and } \\
\text { success } \\
\text { - Also some experiences involving Appreciation }\end{array}$ \\
\hline Safety-security & $\begin{array}{l}\text { Climate: working environment positive, open, honest-feeling, } \\
\text { relaxed, psychological feeling of the workplace } \\
\text { - Supervisor/mentor: working for an especially good supervisor, } \\
\text { something positive supervisor did, special guidance or feedback } \\
\text { from authority figure } \\
\text { - Resources: materials, time, help needed for work provided; good } \\
\text { compensation; working conditions provide sense of security, } \\
\text { stability } \\
\text { - Triumph: victory over negative harmful experiences, especially } \\
\text { when these threatened feelings of security/safety }\end{array}$ \\
\hline
\end{tabular}


Table 2: Frequency Positive-Experience Type

\begin{tabular}{|c|c|c|}
\hline Type & Frequency $(\% *)$ & Discourse \\
\hline Recognition & $236(28.3)$ & Individualism/Uniqueness \\
\hline Relationships & $186(22.3)$ & Belonging/Connection \\
\hline Reward & 137 (16.4) & Individualism/Uniqueness \\
\hline Autonomy & $85(10.2)$ & Power/Empowerment \\
\hline Appreciation & 81 (9.7) & Individualism/Uniqueness \\
\hline Success & $80(9.6)$ & Success/Accomplishment \\
\hline Supervisor/Mentor & $77(9.2)$ & Safety/Security \\
\hline Climate & $62(7.4)$ & Safety/Security \\
\hline Opportunity & $58(6.9)$ & Success/Accomplishment \\
\hline Teamwork & $55(6.6)$ & Belonging/Connection \\
\hline Resources & $44(5.3)$ & Safety/Security \\
\hline Altruistic Work & $33(4.0)$ & Power/Empowerment \\
\hline Voice & $30(3.6)$ & Power/Empowerment \\
\hline Social Support & $26(3.1)$ & Belonging/Connection \\
\hline Flexibility & $22(2.6)$ & Power/Empowerment \\
\hline Challenge & $10(1.2)$ & Success/Accomplishment \\
\hline Triumph & $10(1.2)$ & Safety/Security \\
\hline
\end{tabular}

*Indicates percentage of 835 respondents' experiences 


\section{References}

Adorno, T. W. (1973). Negative dialectics. London: Continuum Publishing Group.

Alvesson, M., \& Kärreman, D. (2000). Varieties of discourse: On the study of organizations through discourse analysis. Human Relations, 53(9), 1125-1149. doi: 10.1177/0018726700539002.

Amabile, T. M., Barsade, S. G., Mueller, J. S., \& Staw, B. M. (2005). Affect and creativity at work. Administrative Science Quarterly, 50(3), 367-403

Anderson, C., \& Thompson, L. L. (2004). Affect from the top down: How powerful individuals' positive affect shapes negotiations. Organizational Behavior and Human Decision Processes, 95(2), 125139 doi: doi:10.1016/j.obhdp.2004.05.002.

Barge, J. K. (2003). Hope, communication, and community building. Southern Communication Journal, 69, 63-81.

Bellah, R. N., Madsen, R., Sullivan, W. M., Swidler, A., \& Tipton, S. M. (1985). Habits of the heart: Individualism and commitment in American life. Berkeley: University of California Press.

Bloch, S. (2001). Positive deviants and their power on transformational leadership. Journal of Change Management, 1, 273-230.

Bolte, A., Goschkey, T., \& Kuhl, J. (2003). Emotion and intuition: Effects of positive and negative mood on implicit judgments of semantic coherence. Psychological Science, 14, 416-421.

Bono, J. E., \& Ilies, R. (2006). Charisma, positive emotions and mood contagion. The Leadership Quarterly, 17(4), 317-334. doi: doi:10.1016/j.leaqua.2006.04.008.

Bryan, T., \& Bryan, J. (1991). Positive mood and math performance. Journal of Learning Disabilities, 24, 490-494.

Buzzanell, P. M., Shenoy, S., Remke, R. V., \& Lucas, K. (2009). Responses to destructive organizational contexts: Intersubjectively creating resilience to foster human dignity and hope. In P. LutgenSandvik \& B. D. Sypher (Eds.), Destructive organizational communication: Processes, consequences, and constructive ways of organizing. (pp. 293-315). New York: Routledge/Taylor \& Francis. 
Buzzanell, P. M., \& Turner, L. H. (2003). Emotion work revealed by job loss discourse: Backgroundingforegrounding of feelings, construction of normalcy, and (re)instituting of traditional male masculinities. Journal Applied Communication Research, 31(1), 27-57.

Cameron, K. S. (2008). Positive leadership: Strategies for extraordinary performance. San Francisco: Berrett-Koehler Publishers, Inc.

Cameron, K. S., Bright, D., \& Caza, A. (2004). Exploring the relationships between organizational virtuousness and performance. The American Behavioral Scientist, 47(6), 766-789.

Cameron, K. S., Dutton, J. E., \& Quinn, R. E. (2003). Foundations of positive organizational scholarship. In K. S. Cameron, J. E. Dutton \& R. E. Quinn (Eds.), Positive organizational scholarship (pp. 313). San Francisco: Berrett-Koehler.

Carnevale, P. J. D., \& Isen, A. M. (1986). The influence of positive affect and visual access on the discovery of integrative solutions in bilateral negotiation. Organizational Behavior and Human Decision Processes, 37(1), 1-13. doi: 10.1016/0749-5978(86)90041-5.

Charmaz, K. (2001). Grounded theory. In R. M. Emerson (Ed.), Contemporary field research (pp. 335352). Prospect Heights, IL: Waveland Press.

Craig, R. T. (1999). Communication theory as a field. Communication Theory, 9(2), 119-161. http://www.wiley.com/bw/aims.asp?ref=1050-3293\&site=1

Danner, D. D., Snowdon, D. A., \& Friesen, W. V. (2001). Positive emotions in early life and longevity: Findings from the nun study. Journal of Personality and Social Psychology, 80(5), 804-813. doi: 10.1037/0022-3514.80.5.804.

Davies, B., \& Harré, R. (1991). Positioning: The discursive production of selves. Journal for the Theory of Social Behaviour, 20(1), 44-36.

Derrida, J. (1974). Of grammatology. London: John Hopkins University Press.

Djamasbi, S. (2007). Does positive affect influence the effective usage of a Decision Support System? Decision Support Systems, 43(4), 1707-1717. doi: 10.1016/j.dss.2006.09.002.

Du Gay, P. (1996). Consumption and identity at work. London: Sage. 
Dutton, J. E., \& Ragins, B. R. (Eds.). (2006). Exploring positive relationships at work: Building a theoretical and research foundation. Philadelphia: Lawrence Erlbaum, Inc.

Emmons, R. A., \& McCullough, M. E. (2003). Counting blessings versus burdens: An experimental investigation of gratitude and subjective well-being in daily life. Journal of Personality \& Social Psychology, 84, 377-389.

Fazio, R. H. (1987). Self-perception theory: A current perspective. In M. P. Zanna, J. M. Olson \& C. P. Herman (Eds.), Social influence: The Ontario Symposium (Vol. 5, pp. 129-150). Mahwah, NJ: Lawrence Erlbaum Associates, Inc.

Feeley, T. H., Hwang, J., \& Barnett, G. A. (2008). Predicting employee turnover from friendship networks. Journal of Applied Communication Research, 36(1), 56-73. doi: 10.1080/00909880701799790.

Fineman, S. (Ed.). (2008). The emotional organization: Passions and power. Carlton, Victoria, Australia: Blackwell Publishing Ltd.

Floyd, K., Mikkelson, A. C., Hesse, C., \& Pauley, P. M. (2007). Affectionate writing reduces total cholesterol: Two randomized, controlled trials. Human Communication Research, 33, 119-142.

Foucault, M. (1972). The archeology of knowledge (A. M. S. Smith, Trans.). New York: Pantheon.

Fredrickson, B. L. (1998). What good are positive emotions? Review of General Psychology, 2(3), 300319.

Fredrickson, B. L. (2003). Positive emotions and upward spirals in organizations. In K. S. Cameron, J. E. Dutton \& R. E. Quinn (Eds.), Positive organizational scholarship (pp. 163-175). San Francisco: Berrett-Koehler.

Fredrickson, B. L. (2005). Positive emotions. In C. R. Snyder \& S. J. Lopez (Eds.), Handbook of positive psychology (pp. 120-134). New York: Oxford University Press.

Fredrickson, B. L., \& Branigan, C. (2005). Positive emotions broaden the scope of attention and thoughtaction repertoires. Cognition and Emotion, 19(3), 313-332. 
Fredrickson, B. L., \& Dutton, J. E. (2008). Unpacking positive organizing: Organizations as sites of individual and group flourishing. The Journal of Positive Psychology, 3(1), 1-3.

Fredrickson, B. L., Mancuso, R. A., Branigan, C., \& Tugade, M. M. (2000). The undoing effect of positive emotions. Motivation and Emotion, 24, 237-258.

Frost, P. J., Dutton, J. E., Worline, M. C., \& Wilson, A. (2000). Narratives of compassion in organizations. In S. Fineman (Ed.), Emotion in organizations (pp. 25-45). Thousand Oaks, CA: Sage.

George, J. M., Brief, A. P., \& Motowidlo, S. J. (1996). Motivational agendas in the workplace: The effects of feelings on focus of attention and work motivation. In L. Cummings \& B. W. Staw (Eds.), Research in organizational behavior (Vol. 18, pp. 75-109). Greenwich, CT: JAI.

Giddens, A. (1984). The constitution of society. Berkeley, CA: University of California Press.

Giddens, A. (1991). Modernity and self-identity. Stanford, CA: Stanford University Press.

Gomez, C., \& Rosen, B. (2001). The leader-member exchange as a link between managerial trust and employee empowerment. Group and Organization Management, 26, 53-69.

Gómez, L. F. (2009). Time to socialize: Organizational socialization structures and temporality. Journal of Business Communication, 46(2), 179-207. doi: 10.1177/0021943608328077.

Grawitch, M. J., Munz, D. C., \& Kramer, T. J. (2003). Effects of member mood states on creative performance in temporary workgroups. Group Dynamics, Theory, Research, and Practice, 7(1), 41-54.

Guest, D. (1990). Human resource management and the American dream. Journal of Management Studies, 27, 377-397.

Hamel, S. A. (2009). Exit, voice, and sensemaking following psychological contract violations: Women's responses to career advancement barriers. Journal of Business Communication, 46(2), 234-261. doi: 10.1177/0021943608328079.

Harré, R. (1986). An outline of the social constructionist viewpoint. In R. Harré (Ed.), The Social Construction of Emotions (pp. 2-14). New York: Basil Blackwell. 
Herzberg, F., Mausner, B., \& Snyder, B. B. (1959). The motivation to work. New York: Wiley.

Hochschild, A. R. (1983). The managed heart: Commercialization of human feeling. Berkeley, CA: University of California Press.

Horan, S. M., \& Chory, R. M. (2009). When work and love mix: Perceptions of peers in workplace romances. Western Journal of Communication, 73(4), 349-369. doi: 10.1080/10570310903279042.

Isen, A. M. (2001). An influence of positive affect on decision making in complex situations: Theoretical issues with practical implications. Journal of Consumer Psychology, 11(2), 75-85.

Isen, A. M., \& Baron, R. (1991). Positive affect as a factor in organizational behavior. In L. L. Cummings \& B. W. Staw (Eds.), Research in organizational behavior (Vol. 13, pp. 1-53). Greenwich, CT: JAI Press.

Isen, A. M., Daubman, K. A., \& Nowicki, G. P. (1987). Positive affect facilitates creative problem solving. Journal of Personality and Social Psychology, 52(6), 1122-1131.

Isen, A. M., \& Levin, P. F. (1972). The effect of feeling good on helping: Cookies and kindness. Journal of Personality and Social Psychology Bulletin, 21, 384-388.

Isen, A. M., \& Means, B. (1983). The influence of positive affect on decision-making strategy. Social Cognition, 2(1), 18-31.

Kemper, T. D. (1978). The social interactional theory of emotions. New York: Wiley.

Kivimäki, M., Ferrie, J. E., Brunner, E., Head, J., Shipley, M. J., Vahtera, J., et al. (2004). Justice at work and reduced risk of coronary heart disease among employees. Archives of Internal Medicine, 165, 2245-2251.

LeBaron, C. D., Glenn, P., \& Thompson, M. P. (2009). Identity work during boundary moments: Managing positive identities through talk and embodied interaction. In L. M. Roberts \& J. E. Dutton (Eds.), Exploring positive identities and organizations. New York: Routledge.

Lindlof, T. R., \& Taylor, B. C. (2002). Qualitative Communication Research Methods (2nd ed.). Thousand Oaks, CA: Sage. 
Lutgen-Sandvik, P., \& Sypher, B. D. (Eds.). (2009). Destructive organizational communication:

Processes, consequences, and constructive ways of organizing. New York: Routledge/Taylor \& Francis.

Luthans, F. (2002). The need for and meaning of positive organizational behavior. Journal of Organizational Behavior, 23, 695-706.

Maslow, A. (1943). A theory of human motivation. Psychological Review, 50, 370-396.

Moore, B. S., Underwood, B., \& Rosenhan, D. L. (1973). Affect and altruism. Developmental Psychology, 8(1), 99-104. http://www.apa.org/journals/dev/

Mumby, D. (2001). Power and politics. In F. M. Jablin \& L. L. Putnam (Eds.), The new handbook of organizational communication (pp. 585-624). Thousand Oaks, CA: Sage.

Parkinson, B. (1996). Emotions are social. British Journal of Psychology, 87, 663-683.

Roberts, L. M., \& Dutton, J. E. (Eds.). (2009). Exploring positive identities and organizations: Building a theoretical and research foundation. New York: Taylor \& Francis.

Sias, P. M. (2005). Workplace relationship quality and employee information experiences. Communication Studies, 56(4), 375-395. doi: 10.1080/10510970500319450.

Sias, P. M., \& Cahill, D. J. (1998). From coworkers to friends: The development of peer friendships in the workplace. Western Journal of Communication, 62, 273-299.

Son-Hing, L. S., Bobocel, R. D., \& Zanna, M. P. (2002). Meritocracy and opposition to affirmative action: Making concessions in the face of discrimination. Journal of Personality and Social Psychology, 83, 493-509.

Steiner, D. D., \& Rain, J. S. (1989). Immediate and delayed primacy and recency effects in performance evaluation. Journal of Applied Psychology, 74(1), 136-142. doi: 10.1037/0021-9010.74.1.136.

Suutari, V., \& Mäkelä, K. (2007). The career capital of managers with global careers. Journal of Managerial Psychology, 22(7), 628-648. doi: 10.1108/02683940710820073. 
Taylor, J. R., Flanagin, A. J., Cheney, G., \& Seibold, D. R. (2001). Organizational communication research: Key moments, central concerns, and future challenges. Communication Yearbook, 24, 99-133.

Waldron, V. R. (2000). Relational experiences and emotions at work. In S. Fineman (Ed.), Emotion in organizations (pp. 64 - 82). Thousand Oaks, CA: Sage.

Wetherby, A. M., Warren, S. F., \& Reichle, J. (Eds.). (1998). Transitions in prelinguistic communication. Baltimore, MD: Paul H. Brookes. .

Wieland, S. M. (2006). Discourses of careerism, separatism, and individualism: A work/life communication response to The opt-out revolution. Electronic Journal of Communication, 16(3/4). http://www.cios.org/www/ejcmain.htm

Young, M. (1961). The rise of the meritocracy, 1870-2033: An essay on education and equality. Baltimore, MD: Penguin Books. 